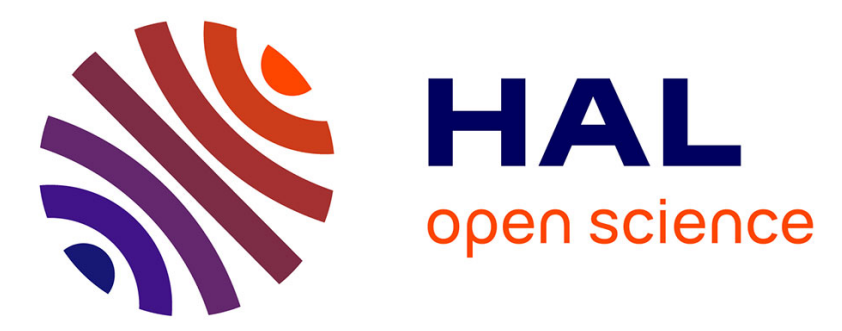

\title{
Effect of aminobisphosphonated copolymer on the thermal stability and flammability of poly(methylmethacrylate)
}

Hossein Vahabi, Claire Longuet, Laurent Ferry, Ghislain David, Jean-Jacques Robin, José-Marie Lopez-Cuesta

\section{To cite this version:}

Hossein Vahabi, Claire Longuet, Laurent Ferry, Ghislain David, Jean-Jacques Robin, et al.. Effect of aminobisphosphonated copolymer on the thermal stability and flammability of poly(methylmethacrylate). Polymer international, 2012, 61, pp.129-134. 10.1002/pi.3158 . hal00624079

\section{HAL Id: hal-00624079 \\ https://hal.science/hal-00624079}

Submitted on 8 Jul 2021

HAL is a multi-disciplinary open access archive for the deposit and dissemination of scientific research documents, whether they are published or not. The documents may come from teaching and research institutions in France or abroad, or from public or private research centers.
L'archive ouverte pluridisciplinaire HAL, est destinée au dépôt et à la diffusion de documents scientifiques de niveau recherche, publiés ou non, émanant des établissements d'enseignement et de recherche français ou étrangers, des laboratoires publics ou privés. 


\title{
Effect of aminobisphosphonated copolymer on the thermal stability and flammability of poly(methyl methacrylate)
}

\author{
Hossein Vahabi, ${ }^{a, b}$ Claire Longuet, $^{a}$ Laurent Ferry, ${ }^{a *}$ Ghislain David, ${ }^{b}$ \\ Jean-Jacques Robin` and José-Marie Lopez-Cuesta ${ }^{a}$
}

\begin{abstract}
Methyl methacrylate was copolymerized with propyl N,N-tetramethylbis(phosphonate)-bis(methylene)aminemethyl methacrylate $\left(\mathrm{MAC}_{3} \mathrm{NP}_{2}\right)$. The thermal degradation and flammability of this modified poly(methyl methacrylate) (PMMA) were compared with those of pure PMMA using thermogravimetric analysis (TGA) and pyrolysis combustion flow calorimetry (PCFC). The morphology of char was investigated using scanning electron microscopy and the yield of phosphorus using energy-dispersive $\mathrm{X}$-ray analysis. The gases evolved during degradation in TGA were analysed using Fourier transform infrared spectroscopy. The total heat release and heat release capacity of the reactively modified PMMA are reduced, as compared to pure PMMA. The modified PMMA presents a better thermal stability (above $290^{\circ} \mathrm{C}$ ) than pure PMMA and leads to an important char formation. A comparison among TGA, PCFC and the amount of phosphorus in the condensed phase gives useful information about the role of phosphorus in the flame retardancy of the copolymer. The result reveals the effect of phosphorus not only in the condensed phase but also in the vapour phase.
\end{abstract}

Keywords: PMMA; thermal behaviour; phosphonated copolymer; pyrolysis combustion flow calorimetry

\section{INTRODUCTION}

Poly(methyl methacrylate) (PMMA) is an important thermoplastic, widely used in industry. ${ }^{1}$ Unfortunately, it is a highly flammable polymer. The flammability of PMMA has been investigated by many research groups. ${ }^{2-5}$ The most common method for improving the fire resistance of PMMA is the physical incorporation of flame-retardant additives (halogenated compounds, phosphorus, nanoparticles or organoclay ${ }^{6}$ ) using melt blending or in situ polymerization procedures. ${ }^{7,8}$ However, because of the several disadvantages of this approach (e.g. high loading, which is detrimental to mechanical properties) an alternative approach was reported. ${ }^{9}$ This alternative approach is the chemical incorporation of flame-retardant species via copolymerization. It appears that the chemical incorporation of these additives is a more effective method for reducing the flammability of PMMA than their physical incorporation. Price et al. ${ }^{9}$ suggested that the physical incorporation of diethyl ethylphosphonate results mainly in a vapour-phase action with a poor production of solid residue. Conversely, the reactive copolymerization of diethyl methacryloyloxymethylphosphonate with methyl methacrylate (MMA) leads to different flame-retardancy mechanisms implying both condensed-phase (char-forming) and vapour-phase actions.

In another paper, ${ }^{4}$ Price et al. compared different MMA comonomers containing phosphate or phosphonate groups. They concluded that phosphates are more effective flame retardants than phosphonates without giving an explanation for these results. More recently, a similar study was carried out with polystyrene. ${ }^{10}$ The authors of that study came to the same conclusions regarding the respective efficiency of phosphate and phosphonate comonomers. Considering that char formation and crosslinking are related to the presence of strong acids generated during the first stage of pyrolysis, it was proposed that the production of volatile products is more inhibited in the case of phosphates because phosphoric acid is a stronger acid than phosphonic acid.

In the work reported in the present study, it was proposed to test a reactive approach in order to improve the thermal stability and reduce the flammability of pure PMMA. An aminobisphosphonated comonomer $\left(\mathrm{MAC}_{3} \mathrm{NP}_{2}\right.$ ) was synthesized and copolymerized with MMA. The choice of this comonomer is justified by the presence of phosphorus atoms and also by previous studies that have shown interesting results with the simultaneous presence of phosphorus and nitrogen. ${ }^{11,12}$ Thermal degradation of samples was studied using TGA in nitrogen and air atmospheres. The flammability of

\footnotetext{
Correspondence to: Laurent Ferry, Ecole des Mines d'Alès, Centre des Matériaux (CMGD) - Pôle Matériaux Polymères Avancés, 6 Avenue de Clavières, 30319 Ales Cedex, France. E-mail: Laurent.Ferry@mines-ales.fr

a Ecole des Mines d'Alès, Centre des Matériaux (CMGD)-Pôle Matériaux Polymères Avancés, 6 Avenue de Clavières, 30319 Ales Cedex, France

b Institut Charles Gerhardt, Montpellier, UMR CNRS 5253, Equipe Ingénierie et Architectures Macromoléculaires, Ecole Nationale Supérieure de Chimie de Montpellier, 8 rue de l'école normale, 34296 Montpellier Cedex 5, France

c Institut Charles Gerhardt, Montpellier, UMR CNRS 5253, Equipe Ingénierie et Architectures Macromoléculaires, Université Montpellier II, Place Eugène Bataillon, 34095 Montpellier Cedex 5, France
} 


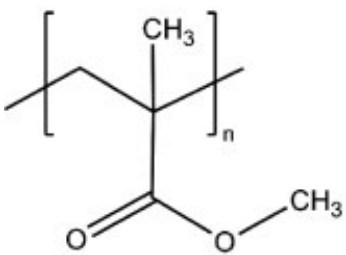

(a)

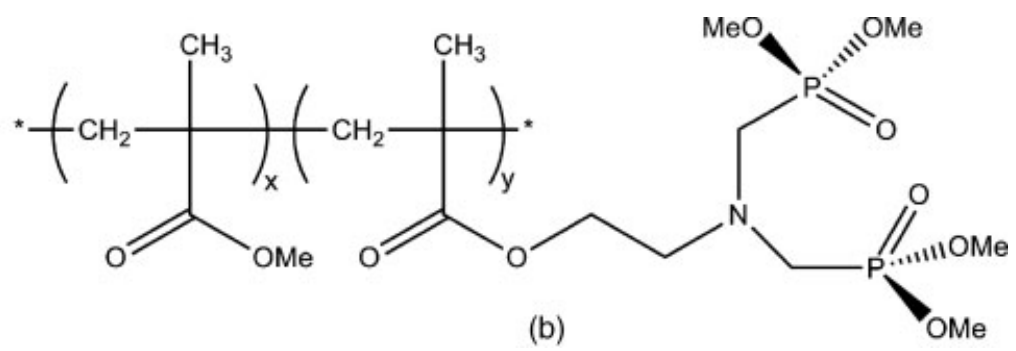

(b)

Scheme 1. Structural formulae of (a) pure PMMA and (b) modified PMMA (aminobisphosphonated copolymer).

samples was assessed using pyrolysis combustion flow calorimetry (PCFC), and gases evolved during TGA were characterized using Fourier transform infrared (FTIR) spectroscopy.

\section{EXPERIMENTAL}

\section{Materials and methods}

Both pure PMMA and modified PMMA (i.e. aminobisphosphonated copolymer) (Scheme 1) were synthesized via radical polymerization. Pristine PMMA was polymerized in tetrahydrofuran at $70^{\circ} \mathrm{C}$ using azobisisobutyronitrile (AIBN) as initiator. Finally, the synthesized PMMA was precipitated with methanol. The synthesis of copolymer was carried out via three reaction steps. In the first step, a Kabachnik-Fields reaction allowed the synthesis of aminobisphosphonate alcohol $\left(\mathrm{HOC}_{3} \mathrm{NP}_{2}\right)$. The second step involved the methacrylation of this alcohol with methacryloyl chloride leading to aminobisphosphonated methyl methacrylate $\left(\mathrm{MAC}_{3} \mathrm{NP}_{2}\right)$. The third step was radical copolymerization of $\mathrm{MAC}_{3} \mathrm{NP}_{2}$ with $\mathrm{MMA}$ carried out in chloroform at $70^{\circ} \mathrm{C}$ and initiated by AIBN.

The chemical structures of the products were assessed using ${ }^{1} \mathrm{H}$ NMR, ${ }^{31} \mathrm{P}$ NMR and ${ }^{13} \mathrm{C}$ NMR. The molecular weight was measured, with PMMA equivalent, using SEC (pure PMMA: $M_{\mathrm{n}}=16000 \mathrm{~g} \mathrm{~mol}^{-1}$, index of polydispersity (IP) = 1.66; modified PMMA: $M_{\mathrm{n}}=4600 \mathrm{~g} \mathrm{~mol}^{-1}, \mathrm{IP}=1.32$ ). The syntheses and the characterization are described in detail elsewhere. ${ }^{13}$ In the case of the copolymer, the molar ratio between comonomers was fixed at $1: 1$. The amount of phosphorus in the copolymer was $12.7 \mathrm{wt} \%$. All polymers were vacuum-dried at $120^{\circ} \mathrm{C}$ for $12 \mathrm{~h}$.

Thermal decomposition was investigated using a PerkinElmer Pyris-1 TGA instrument. All measurements were performed under nitrogen and air with a heating rate of $10{ }^{\circ} \mathrm{C} \mathrm{min}^{-1}$. The sample weight was $8 \pm 2 \mathrm{mg}$.

SEM (FEl Quanta 200 SEM) was used to study the morphology of the residues. All images were obtained under high vacuum at a voltage of $15.0 \mathrm{kV}$. Analysis of the percentage of phosphorus in the char residue was carried out using energy-dispersive X-ray analysis (EDX) with an Oxford INCA Energy 300 and a detector of $133 \mathrm{eV}$ resolution (at $M_{\mathrm{n}}$ ). The residues obtained from TGA (under nitrogen) at various temperatures were directly observed. The residues were ground between two glass microscope slides to render them homogeneous and compressed to form a compact and smooth layer before analysis.

Evaluation of the flammability properties was made using PCFC (Fire Testing Technology Co.). Samples ( $\pm 0.5 \mathrm{mg}$ ) were heated at $1 \mathrm{~K} \mathrm{~s}^{-1}$ from 100 to $750{ }^{\circ} \mathrm{C}^{14}$ in a pyrolyser and the degradation products were transported by an inert flux, and then mixed with oxygen before entering a combustor at $900{ }^{\circ} \mathrm{C}$ where the decomposition products were completely oxidized. The heat release rate (HRR) was measured as function of temperature. In order to compare materials, the heat release capacity (HRC;
Table 1. TGA parameters of pure and modified PMMA under nitrogen atmosphere

\begin{tabular}{lcccc} 
Sample & $T_{5 \%}\left({ }^{\circ} \mathrm{C}\right)$ & $T_{10 \%}\left({ }^{\circ} \mathrm{C}\right)$ & $T_{50 \%}\left({ }^{\circ} \mathrm{C}\right)$ & Char $(\mathrm{wt} \%)^{\mathrm{a}}$ \\
\hline PMMA & 270 & 274 & 362 & 0 \\
Modified PMMA & 238 & 274 & 407 & 18
\end{tabular}

${ }^{\text {a }}$ Char residue at $900{ }^{\circ} \mathrm{C}$.

$\mathrm{J} \mathrm{g}^{-1} \mathrm{~K}^{-1}$ ) is usually determined. HRC refers to the ratio of peak HRR with heating rate. In our case, the decomposition of samples involved several steps. Therefore, sumHRC was used rather than HRC, where sumHRC is the sum of HRC values of every decomposition peak after deconvolution performed with Fire Testing Technology software. The PCFC and TGA runs were repeated twice for each sample and good repeatability was observed.

The TGA instrument was coupled to an FTIR spectrometer (Bruker-IFS66) to analyse the evolved gases. The heating rate and sample weight were identical to those of a simple TGA run $\left(10^{\circ} \mathrm{C} \mathrm{min}^{-1}\right.$ and $\left.8 \mathrm{mg}\right)$. The evolved gases were transferred into the FTIR spectrometer via a heated line (at $200^{\circ} \mathrm{C}$ ) with a nitrogen flow rate of $20 \mathrm{~mL} \mathrm{~min}^{-1}$. FTIR spectra were obtained by averaging eight scans and recorded in the region $400-4000 \mathrm{~cm}^{-1}$ with a spectral resolution of $1 \mathrm{~cm}^{-1}$.

\section{RESULTS AND DISCUSSION}

\section{Thermogravimetric analysis}

The TGA and derivative thermogravimetric (DTG) curves of pure PMMA and modified PMMA (aminobisphosphonated copolymer) are shown in Fig. 1. The TGA data are given in Table 1. As can be seen in Fig. 1(a), pure PMMA and modified PMMA exhibit significantly different thermal stabilities. The thermal degradation of PMMA occurs in two steps of weight loss. According to other authors $^{15-18}$ the different steps of degradation of PMMA correspond to the different types of polymer chains obtained by radical polymerization. The first step of degradation (ca $290^{\circ} \mathrm{C}$ ) takes place by scission at unsaturated ends (resulting from termination by disproportionation) involving a homolytic $\beta$-scission of the vinyl group. The second step $\left(\mathrm{ca} 390^{\circ} \mathrm{C}\right)$ is a random scission within the polymer chain.

The thermal degradation of modified PMMA proceeds in three steps. The first and second steps of degradation occur at approximately the same temperatures as those of pure PMMA (ca 300 and $400{ }^{\circ} \mathrm{C}$, respectively). The third step is located at ca $500^{\circ} \mathrm{C}$. This step of degradation was investigated in more detail in the present study. 

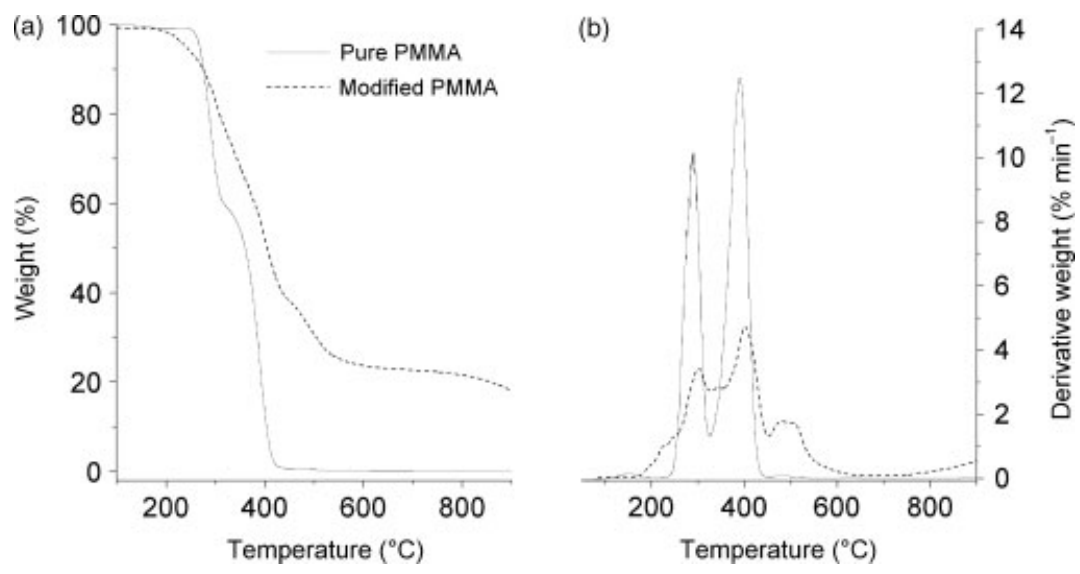

Figure 1. (a) TGA and (b) DTG curves for pure PMMA and modified PMMA obtained at a heating rate of $10^{\circ} \mathrm{Cmin}^{-1}$ under nitrogen.
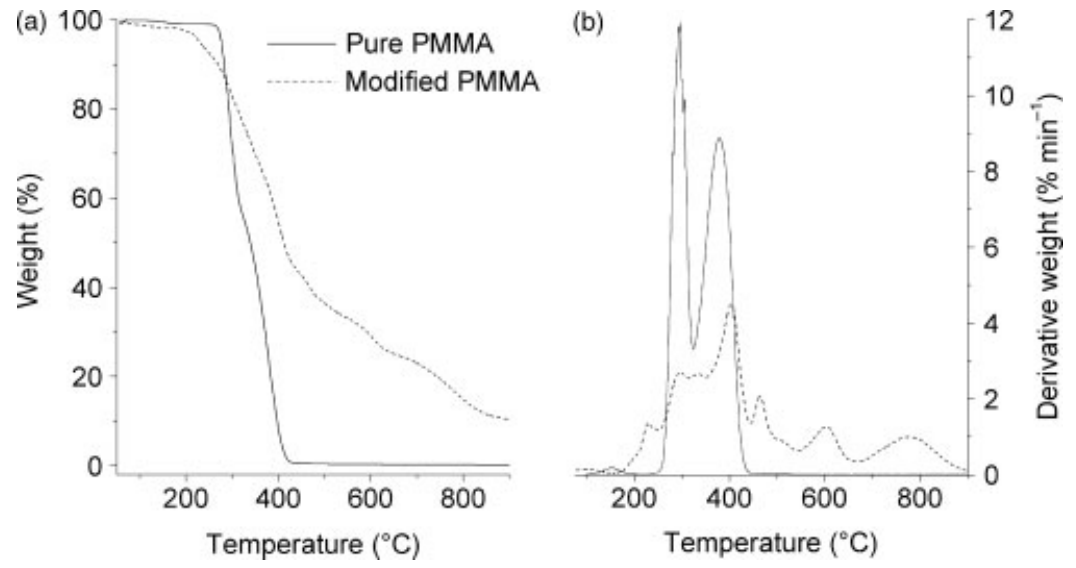

Figure 2. (a) TGA and (b) DTG curves for pure PMMA and modified PMMA at a heating rate of $10^{\circ} \mathrm{Cmin}^{-1}$ under air.

\begin{tabular}{|c|c|c|c|c|}
\hline Sample & $T_{5 \%}\left({ }^{\circ} \mathrm{C}\right)$ & $T_{10 \%}\left({ }^{\circ} \mathrm{C}\right)$ & $T_{50 \%}\left({ }^{\circ} \mathrm{C}\right)$ & Char (wt\%) \\
\hline PMMA & 279 & 284 & 337 & 0 \\
\hline Modified PMMA & 228 & 270 & 412 & 13 \\
\hline
\end{tabular}

The onset temperatures of thermal degradation occur at 250 and $190^{\circ} \mathrm{C}$ for pure PMMA and modified PMMA, respectively. The amount of char formed is up to $18 \mathrm{wt} \%$ at $900^{\circ} \mathrm{C}$ for modified PMMA. In the case of pure PMMA, there is no char at the end of the TGA experiments.

The thermal degradation of samples was also investigated in air. The TGA data are given in Table 2. Figures 2(a) and (b) show the TGA and DTG curves, respectively, of the samples in air. It appears that the degradation pathway observed under air is similar to that under nitrogen for pure PMMA. However, a slight improvement in thermal stability is observed for pure PMMA at 5 and $10 \%$ weight loss. This improvement can be explained in terms of a stabilizing effect of oxygen, also observed by other authors. ${ }^{17,19}$ In the case of the modified PMMA, two more steps of degradation are observed above $550{ }^{\circ} \mathrm{C}$. According to the literature, these steps (ca 600 and $780^{\circ} \mathrm{C}$ ) are due to the degradation of char residue. ${ }^{9}$ The char yield

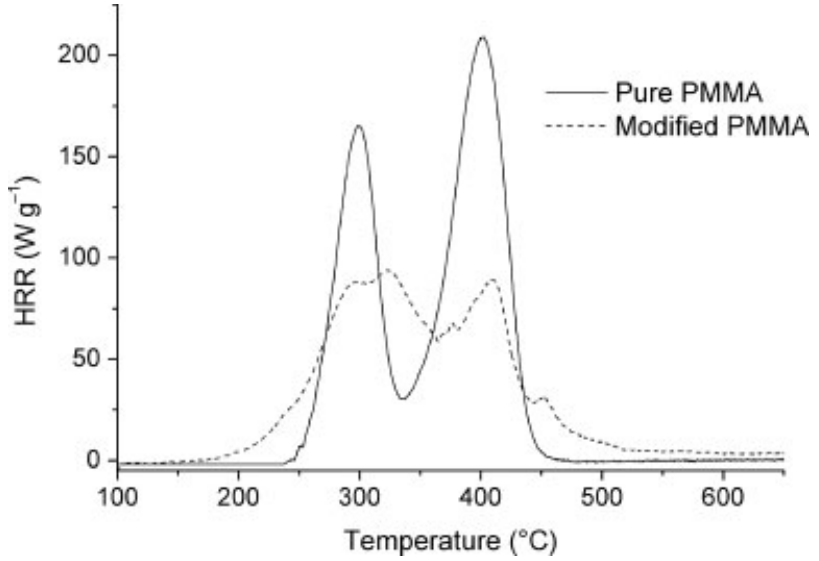

Figure 3. HRR curves of pure PMMA and modified PMMA.

of modified PMMA obtained under air atmosphere is less than that obtained under nitrogen atmosphere (10 wt\%).

\section{PCFC analysis}

PCFC uses oxygen consumption calorimetry to measure both the rate and amount of heat produced by complete combustion of the fuel gases generated during controlled pyrolysis of a milligram-sized sample. ${ }^{20}$ Several studies show that PCFC is a 


\begin{tabular}{|c|c|c|c|c|c|}
\hline Sample & $\begin{array}{l}\text { HRR peaks } \\
\left(\mathrm{J} \mathrm{g}^{-1} \mathrm{~K}^{-1}\right)^{\mathrm{a}}\end{array}$ & $\begin{array}{c}\text { Time to peak } \\
\operatorname{HRR}(\mathrm{s})^{\mathrm{a}}\end{array}$ & $\begin{array}{c}\mathrm{HRC} \\
\left(\mathrm{Jg}^{-1} \mathrm{~K}^{-1}\right)\end{array}$ & $\begin{array}{c}\text { THR1 } \\
\left(\mathrm{kJ} \mathrm{g}^{-1}\right)^{\mathrm{b}}\end{array}$ & $\begin{array}{c}\text { THR2 } \\
\left(\mathrm{kJ} \mathrm{g}^{-1}\right)^{\mathrm{c}}\end{array}$ \\
\hline PMMA & 164,208 & 299,402 & 460 & 26 & 26 \\
\hline Modified PMMA & 94,89 & 323,409 & 214 & 15.7 & 18 \\
\hline
\end{tabular}
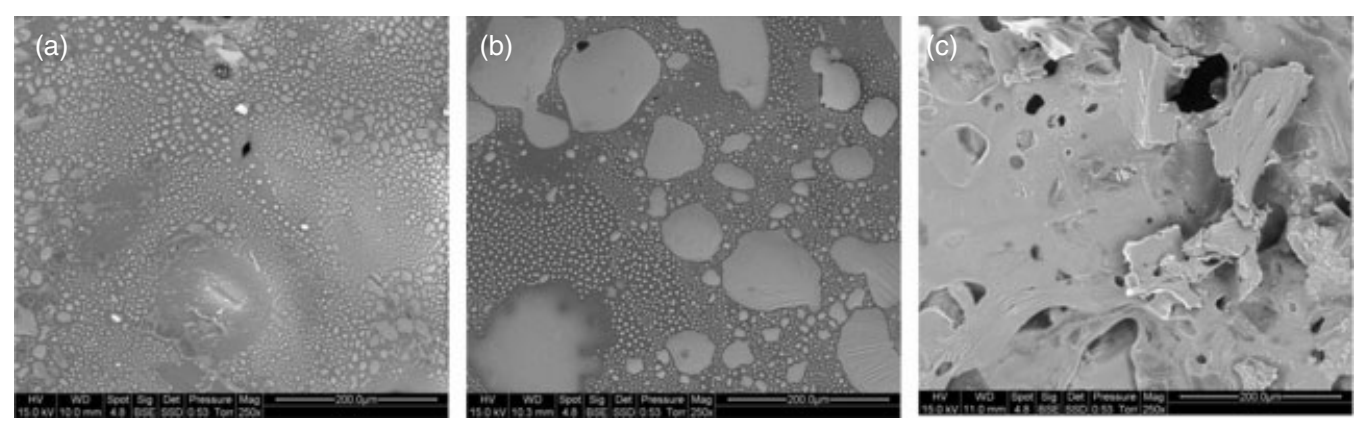

Figure 4. Morphology of residual char of modified PMMA at (a) $300^{\circ} \mathrm{C}$, (b) $400^{\circ} \mathrm{C}$ and (c) $500^{\circ} \mathrm{C}$.

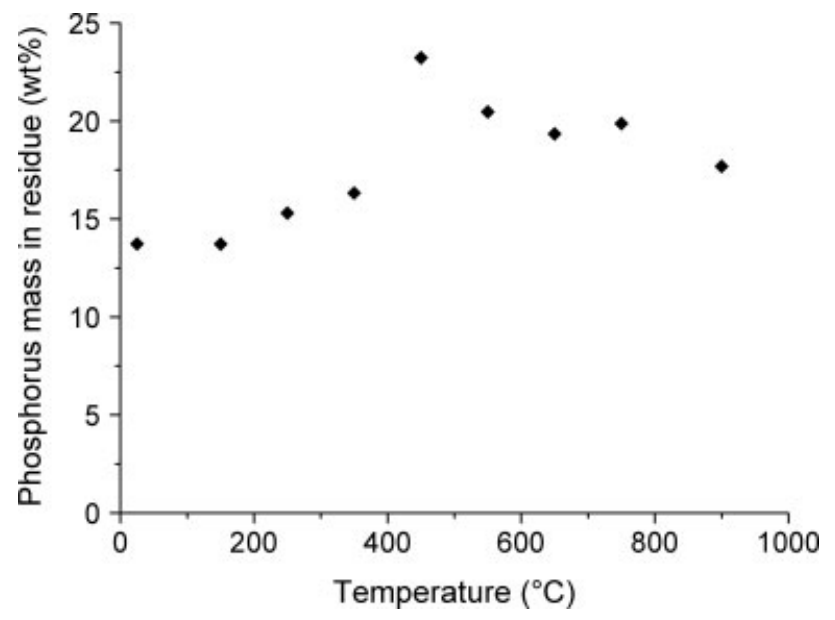

Figure 5. Amount of phosphorus in TGA test residue for modified PMMA.

suitable method for estimating the fire hazard potential of a material. ${ }^{21,22}$

The HRR versus temperature curves of pure PMMA and modified PMMA are shown in Fig. 3. Table 3 lists the total heat release (THR), HRC and peak HRR values for the samples. The results show that the chemical modification of PMMA improves the fire behaviour of this polymer. The HRC value significantly decreases from 460 to $214 \mathrm{~J} \mathrm{~g}^{-1} \mathrm{~K}^{-1}$ for pure PMMA and modified PMMA, respectively. The THR1 value (that relating to the initial sample weight) also decreases. There are two distinct peaks of heat release for both samples. The peaks of HRR of modified PMMA are significantly lower than those of pure PMMA. Dividing THR1 by the percentage of weight loss enables one to determine the energy released per gram of decomposed products (THR2). This calculation shows that the decrease in THR is not only due to char formation but also to the nature of the released gases. The combustion of these gases produces less energy.

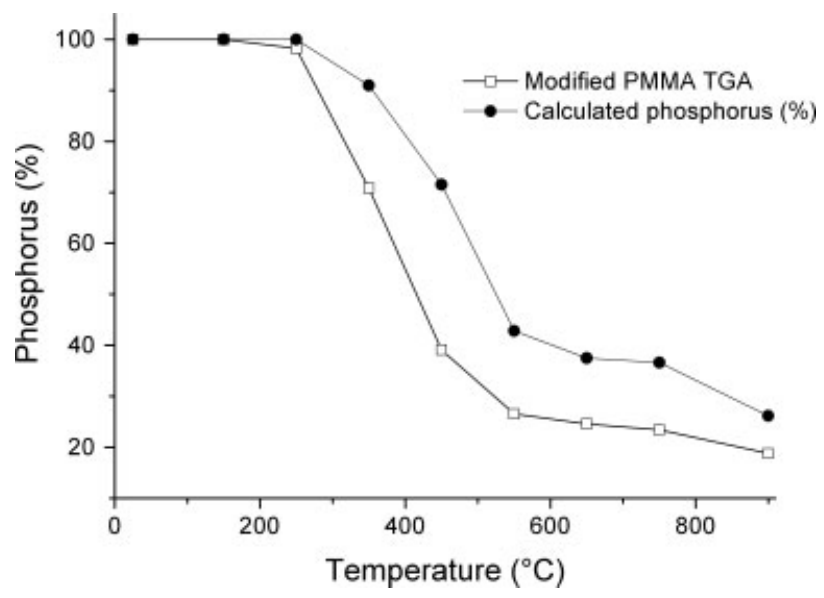

Figure 6. Comparison of modified PMMA TGA curve and calculated percentage of phosphorus.

\section{Analysis of residue: SEM/EDX}

The residue obtained from isothermal TGA experiments was directly observed using SEM. Figure 4 shows SEM images of the residual char at three temperatures. These temperatures correspond to the three steps of degradation of modified PMMA. The SEM investigations show that the residue composition is quite inhomogeneous at 300 and $400{ }^{\circ} \mathrm{C}$. A flaky surface is observed at $300^{\circ} \mathrm{C}$; at $400^{\circ} \mathrm{C}$, this flaky surface is more developed. Finally, at $500^{\circ} \mathrm{C}$, a homogeneous surface is observed.

The decomposition residues obtained from isothermal TGA experiments were also investigated by means of EDX in order to determine the chemical composition (in particular, the amount of phosphorus). Figure 5 shows the amount of phosphorus in the TGA test residues. It can be seen that up to $450{ }^{\circ} \mathrm{C}$ there is an enrichment of phosphorus in the residue. Above $450^{\circ} \mathrm{C}$, a slight decrease is observed and then the amount levels off. These results 

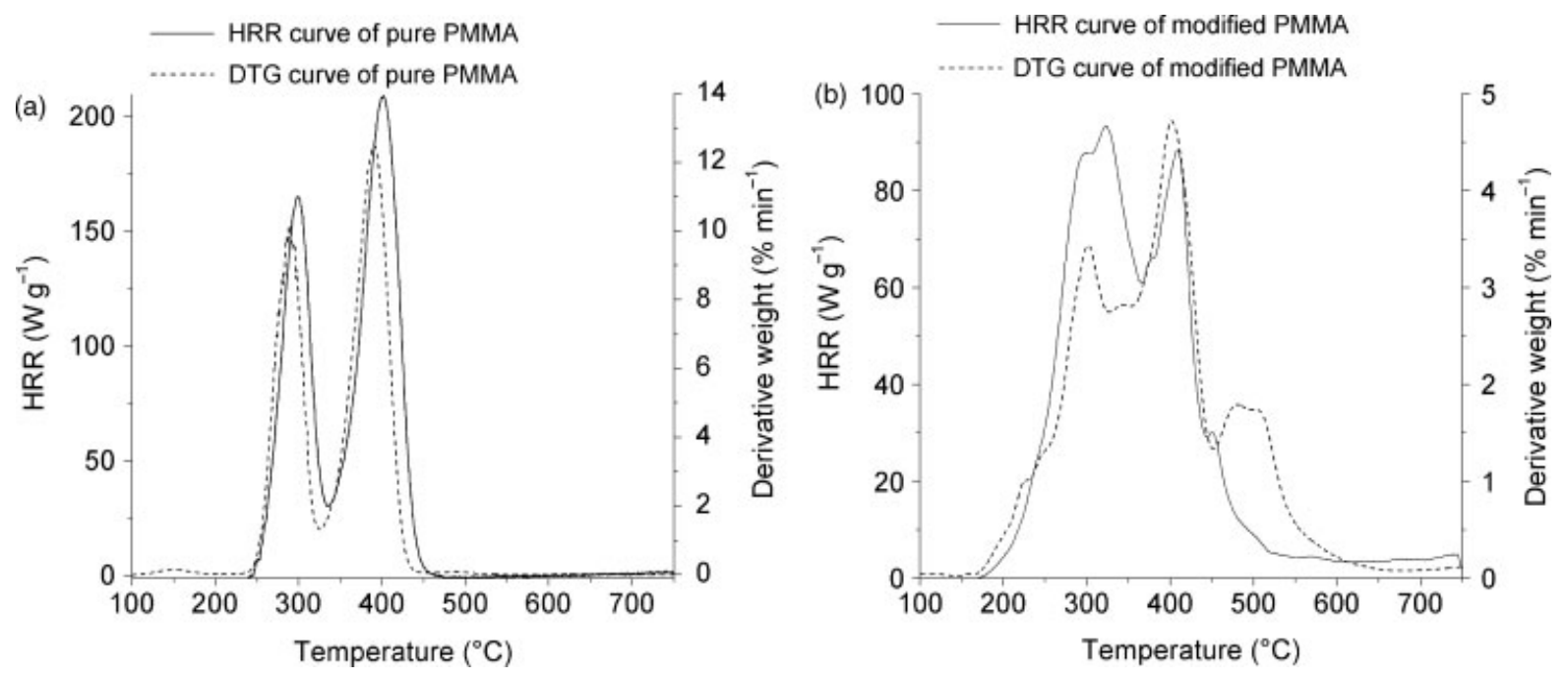

Figure 7. Superposition of DTG and HRR curves of (a) pure PMMA and (b) modified PMMA.

indicate that phosphorus seems to play an important role in the condensed phase, i.e. promoting char formation.

In order to determine the weight loss of phosphorus (\% $\left.\mathrm{P}_{\text {loss }}\right)$, the following equation was used:

$$
\% \mathrm{P}_{\text {loss }}=\frac{\% \mathrm{P}_{\text {residue }} \times[100-(\% \text { weight loss })]}{\% \mathrm{P}_{\text {initial }}}
$$

where $\% \mathrm{P}_{\text {residue }}$ is the phosphorus content of residues quantitatively measured using EDX and \% $\mathrm{P}_{\text {initial }}$ is the initial phosphorus content measured using ${ }^{1} \mathrm{H}$ NMR (12.7 wt\%). These calculations were performed for 10 different temperatures and compared to the TGA curve of modified PMMA. The results are shown in Fig. 6. These curves reveal that the weight loss of phosphorus differs from that of modified PMMA. The phosphorus fraction of the copolymer exhibits a lower decomposition rate than that of the whole copolymer. This difference accounts for the enrichment in phosphorus observed in the condensed phase up to $450{ }^{\circ} \mathrm{C}$. Furthermore, it should be remarked that more than $60 \%$ of the phosphorus is released in the vapour phase below $600^{\circ} \mathrm{C}$.

Figure 7 shows the superposition of DTG and HRR curves for pure PMMA and modified PMMA. In the case of pure PMMA (Fig. 7(a)), a good superposition is observed (two steps of degradation correspond to two steps of heat release). (The observed shift between HRR and DTG curves is related to the different constants of heating rate in TGA and PCFC analysis.) Moreover, the curves are similar in shape, both analyses being done under nitrogen. Therefore, we concluded that whatever the temperature, the energetic value of evolved gases remains constant and there is a complete combustion of all released gases. The superposition of DTG and HRR curves of copolymer (Fig. 7(b)) indicates a marked difference in the third step of degradation. These results suggest that the released gases in the third step of degradation have less energetic value compared to the quantity of released gases.

This type of superposition of DTG and HRR curves was also reported by other authors. ${ }^{22-25}$ Morgan and Galaska ${ }^{23}$ directly concluded (using this method) that the similarity in shape of these curves indicates the pyrolysis of the flammable fuel, and if the curves were not superposed (not aligned), it could be assumed that the weight loss during TGA was frame retardant (FR) or other non-oxygen combustible material.

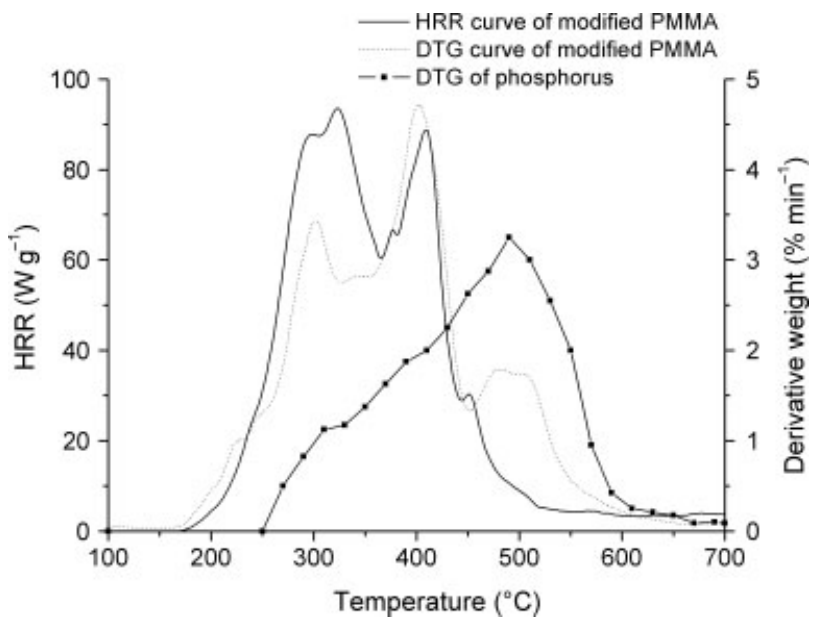

Figure 8. Superposition of DTG, HRR and derivative phosphorus percentage curves of modified PMMA.

Here, we attempt to confirm these primary conclusions using other analytical methods and also to determine the gases evolved during the pyrolysis of the modified PMMA. First, the curve of the percentage of phosphorus (Fig. 6) was derived and superposed with the HRR and DTG curves of modified PMMA. The superposed curves are shown in Fig. 8. This superposition indicates that the most significant evolution of phosphorus in the gas phase occurs at $500^{\circ} \mathrm{C}$. These observations clearly reveal the effect of released phosphorus species on the gaseous phase and its consequence for the HRR curve.

\section{Evolved gas analysis: coupled TGA/FTIR investigation}

The gases evolved during TGA were obtained in an inert atmosphere to avoid interaction with oxygen. Figure 9 shows FTIR spectra of evolved gases of modified PMMA from 264 to $900^{\circ} \mathrm{C}$ during thermal degradation. The spectra of the evolved gases during thermal degradation of modified PMMA show differences in band intensities for $\mathrm{CH}_{3}\left(1440 \mathrm{~cm}^{-1}\right)$, $\mathrm{C}=\mathrm{O}\left(1725 \mathrm{~cm}^{-1}\right.$; corresponding to MMA), $\mathrm{P}-\mathrm{O}-\mathrm{C}\left(1026 \mathrm{~cm}^{-1}\right)$, $\mathrm{P}-\mathrm{O}-\mathrm{CH}_{3}\left(821 \mathrm{~cm}^{-1}\right)$ and $\mathrm{P}=\mathrm{O}\left(1272 \mathrm{~cm}^{-1}\right)$. 


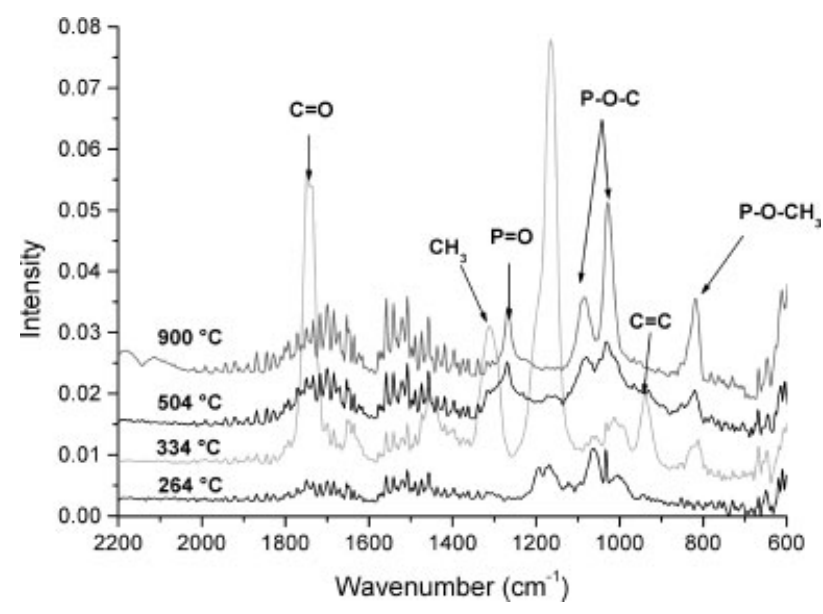

Figure 9. FTIR spectra of gases evolved from modified PMMA at various temperatures.

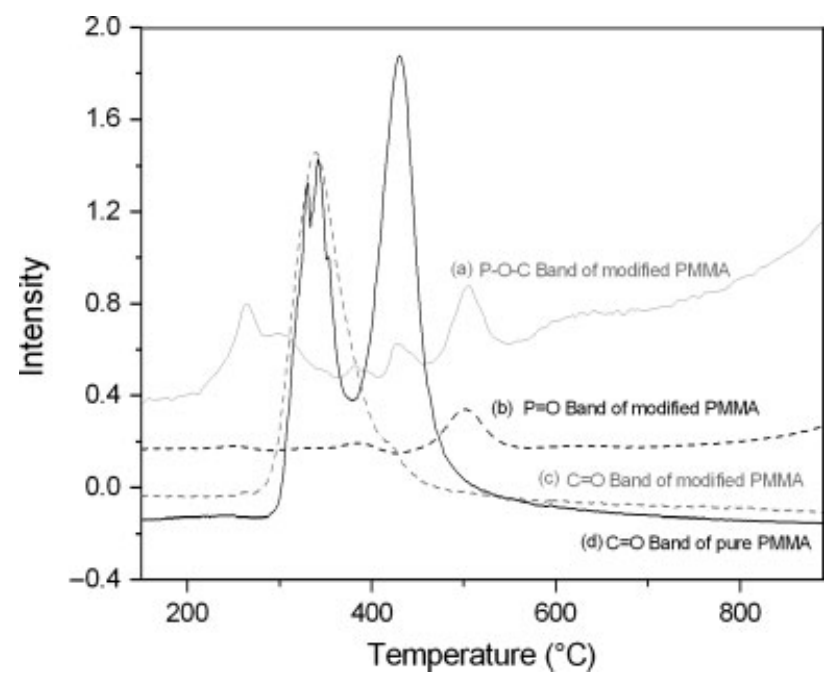

Figure 10. Gram-Schmidt curves as a function of temperature of modified PMMA: (a) $1026 \mathrm{~cm}^{-1} \quad(\mathrm{P}-\mathrm{O}-\mathrm{C}) ; \quad$ (b) $1272 \mathrm{~cm}^{-1} \quad(\mathrm{P}=\mathrm{O})$; (c) $1725 \mathrm{~cm}^{-1}$ $(C=O) ;(d) C=O$ (pure PMMA).

In order to follow the changes in intensity of these peaks during thermal degradation, the intensities of these bands were obtained as a function of temperature. Figure 10 shows these curves for $\mathrm{C}=\mathrm{O}, \mathrm{P}-\mathrm{O}-\mathrm{C}$ and $\mathrm{P}=\mathrm{O}$ bands. These curves seem to indicate that the release of $\mathrm{MMA}(C=O)$ occurs at low temperature $\left(335^{\circ} \mathrm{C}\right)$ and that of phosphorus species $(\mathrm{P}-\mathrm{O}-\mathrm{C}$ and $\mathrm{P}=\mathrm{O})$ at high temperature $\left(500^{\circ} \mathrm{C}\right)$. This observation is in agreement with the results (the release of phosphorus species at $\mathrm{ca} 500^{\circ} \mathrm{C}$ ) of SEM/EDX. Furthermore, a comparison between the $\mathrm{C}=\mathrm{O}$ bands of pure and modified PMMA indicates that the release of $C=0$ occurs in two steps for pure PMMA (340 and $425^{\circ} \mathrm{C}$ ) while for modified PMMA only one step of degradation is observed.

\section{CONCLUSIONS}

A modified PMMA (a novel aminobisphosphonated copolymer) has been synthesized and compared with pure PMMA. The samples have been characterized using TGA/FTIR, microcalorimetry and SEM/EDX. The combination of DTG, microcalorimetry and TGA/FTIR analyses provides very useful information. Furthermore, the chemical composition of the residue was analysed at various temperatures and compared with the evolved gas composition.

The modified PMMA presents a better thermal stability (above $290^{\circ} \mathrm{C}$ ) than pure PMMA and leads to an important char formation (18 wt\%). The result reveals the effect of phosphorus not only in the condensed phase but also in the vapour phase. The exact role of nitrogen was not investigated in this study. A complementary study with a similar copolymer without nitrogen seems necessary to determine the role of nitrogen and also to investigate a possible synergy between nitrogen and phosphorus.

\section{ACKNOWLEDGEMENT}

The authors thank Mr Jean-Marie Taulemesse for assistance with the SEM/EDX analysis.

\section{REFERENCES}

1 Chou WJ, Wang GA, Wang CC, Chena CY, Lin JL and Huang SJ, Polymer 50:5094-5102 (2009)

2 Wang L, Su S, Chen D and Wilkie CA, Polym Degrad Stab 94:1110-1118 (2009).

3 Gentilhomme A, Cochez M, Ferriol M, Oget N and Mieloszynski J, Polym Degrad Stab 82:347-355 (2003).

4 Price D, Pyrah K, Hull TR, Milnes GJ, Ebdon JR, Hunt BJ, et al, Polym Degrad Stab 77:227-233 (2002).

5 Ebdon JR, Price D, Hunt BJ, Joseph P, Gao F, Milnes GJ, et al, Polym Degrad Stab 69:267-277 (2000).

6 Wang L, Xie X, Su S, Feng J and Wilkie CA, Polym Degrad Stab 95:572-578 (2010).

7 Laachachi A, Cochez M, Ferriol M, Leroy E, Lopez Cuesta JM and Ogeta N, Polym Degrad Stab 85:641-646 (2004).

8 Laachachi A, Cochez M, Leroy E, Ferriol M and Lopez-Cuesta JM, Polym Degrad Stab 92:61-69 (2007).

9 Price D, Pyrah K, Hull TR, Milnes GJ, Ebdon JR, Hunt BJ, et al, Polym Degrad Stab 74:441-447 (2001).

10 Price D, Cunliffe LK, Bullett KJ, Hull TR, Milnes GJ, Ebdon JR, et al, Polym Degrad Stab 92:1101-1114 (2007).

11 Weil ED, Synergists, adjuvants and antagonists in flame retardant systems, in Fire Retardancy of Polymeric Materials, ed. by Grand AF and Wilkie CA. Marcel Dekker, New York, pp. 115-145 (1999).

12 Lewin M, Polym Adv Technol 12:215-222 (2001).

13 Chougrani K, Boutevin B, David G and Boutevin G, Eur Polym J 44:1771-1781 (2008).

14 Sonnier R, Ferry L, Longuet C, Laoutid F, Friederich B, Laachachi A, et al, Polym Adv Technol 22:1091-1099 (2011).

15 Kashiwagi T, Inaba A, Brown JE, Hatada K, Kitayama T and Masuda E, Macromolecules 19:2160-2168 (1986).

16 Manring LE, Sogah DY and Cohen GM, Macromolecules 22:4652-4654 (1989).

17 Peterson JD, Vyazovkin S and Wight CA, Macromol Rapid Commun 20:480-483 (1999).

18 Ferriol M, Gentilhomme A, Cochez M, Oget N and Mieloszynski JL, Polym Degrad Stab 79:271-281 (2003).

19 Brown JE and Kashiwagi T, Polym Degrad Stab 52:1 - 10 (1996).

20 Hergenrother PM, Thompson CM, Smith Jr JG, Connell JW, Hinkley JA, Lyon RE, et al, Polymer 46:5012-5024 (2005).

21 Lyon RE and Walters R, Final Report. [Online]. Office of Aviation Research, Washington, DC (2002). Available: http://www.tc.faa.gov/ its/worldpac/techrpt/ar01-117.pdf [18 April 2011].

22 Schartel B, Pawlowski KH and Lyon RE, Thermochim Acta 462:1-14 (2007).

23 Morgan AB and Galaska M, Polym Adv Technol 19:530-546 (2008).

24 Lyon RE and Walters RN, J Anal Appl Pyrolysis 71:27-46 (2004).

25 Lyon RE, Walters RN and Stoliarov SI, Polym Eng Sci 47:1501-1510 (2007). 